\title{
Hepatitis C Virus RNA Measurement
}

National Cancer Institute

\section{Source}

National Cancer Institute. Hepatitis C Virus RNA Measurement. NCI Thesaurus. Code C142330.

The determination of the amount of hepatitis C virus RNA present in a sample. 